\title{
The simulation study on montmorillonite and its effecting to borehole stability *
}

\author{
Xiaodi $\mathrm{Li}^{1, \mathrm{a}}$ Zening Sun ${ }^{1}$ Hongjun $\mathrm{Liu}^{1}$ Jiafang $\mathrm{Xu}^{1, \mathrm{~b}^{*}}$ Yingwen \\ $\mathrm{Ma}^{2}$ \\ 1 College of Petroleum Engineering, China Petroleum University, \\ Qingdao China, 266580 \\ 2 Drilling \& Completion Department of CNOOC Ltd. Tianjin, Tanggu, \\ China, 300452 \\ axiaodi0304@126.com, ${ }^{b}$ xjiafang@upc.edu.cn
}

\begin{abstract}
.
Borehole instability is one of the most complex downhole problems in the drilling process. In order to study the micro-mechanism of inorganic salts on shale hydration, a micro-crystal structure model of Na-montmorillonite was established using the MS software. The shale hydration mechanism, mechanical strength change due to hydration and the inhibition mechanism of inorganic salts were studied by molecule dynamic simulation. The simulation results showed some basic microscopic property, and agreed with the experiment.
\end{abstract}

Keywords: Molecular simulation; Mechanical properties; Inorganic salt; Swelling

\section{Introduction}

The rock strength reduction due to hydration depends on the clay content and the component of clay minerals, especially the content of montmorillonite. Shale inhibitors have an inhibition effect on clay hydration and swelling. Different content and type of shale inhibitors have different inhibition effects[1-3]. Experiments can show the macroscopic mechanism between drilling fluid chemicals and rocks, but they are difficult to reveal microscopic mechanism. Monte-Carlo dynamic simulation showed that the diffusion coefficients of both $\mathrm{Na}^{+}$and water molecule were sharply decreased with $\mathrm{KCl}$ added into the Na-montmorillonite crystal structures[4]. Fangui Zeng, et al studied the microscopic hydration process of Na-montmorillonite, and gave an interlayer space curve changing with absorbing water molecule number[5]. Ping $\mathrm{Na}$, et al found that different type and number of interlayer cation made the montmorillonite showing different swelling behaviors[6]. In this paper, a Na-montmorillonite model was established using the Material Studio (MS) software. The hydration process and mechanism were studied as well as the 
effects of these inorganic salts on montmorillonite strength, and the chemistry and mechanics were coupled together to show how the chemical aspect affected on rock mechanics property. The simulation results showed a good agreement with experiments.

\section{Optimization of Na-montmorillonite model}

According to the basic structure properties of montmorillonite, a Na-montmorillonite crystal model with 8 unit cell $(4 \times 2 \times 1)$ was established. The crystal lattice substitutions were made at the same time, and the negative charges produced by substitution were compensated by $\mathrm{Na}^{+}$.

The Na-montmorillonite interlayer spaces was increased with the addition of water. According to the change of montmorillonite interlayer spaces and unit cell parameters, and considering X-ray diffraction, we found that when water molecules reach 48,72 and 96 , c is $1.25 \mathrm{~nm}, 1.55 \mathrm{~nm}$ and $1.85 \mathrm{~nm}$ respectively, the first, second and third saturated water molecule layer were formed.

\section{Simulation on inorganic cation inhibition mechanism}

\subsection{Ion type}

In this study, seven types of salts were used, which are $\mathrm{NaCl}, \mathrm{KCl}, \mathrm{CaCl}_{2}, \mathrm{NH} 4 \mathrm{Cl}$, $\mathrm{MgCl}_{2}, \mathrm{AlCl}_{3}$ and $\mathrm{FeCl}_{3}$. The coordinate number, hydration number and hydration radius of these cations were calculated. At the same time, the mechanical parameters were analyzed. The results were shown in Table1, Fig.1 and Table2.

Table1 The inorganic cations coordination number, hydration number and hydration radius change with Montmorillonite hydration

\begin{tabular}{ccccc}
\hline $\begin{array}{c}\text { Ion } \\
\text { type }\end{array}$ & $\begin{array}{c}\text { Hydration } \\
\text { layers }\end{array}$ & $\begin{array}{c}\text { Ion coordinate } \\
\text { number }\end{array}$ & $\begin{array}{c}\text { Ion hydration } \\
\text { number }\end{array}$ & $\begin{array}{c}\text { Ion hydration } \\
\text { radius, nm }\end{array}$ \\
\hline \multirow{2}{*}{$\mathrm{Na}^{+}$} & 1 & 8.03 & 5.57 & 3.41 \\
& 3 & 5.26 & 3.63 & 3.00 \\
\hline \multirow{2}{*}{$\mathrm{K}^{+}$} & 1 & 5.00 & 2.00 & 2.43 \\
& 3 & 3.29 & 1.32 & 2.06 \\
\hline \multirow{2}{*}{$\mathrm{NH}_{4}^{+}$} & 1 & 5.55 & 2.18 & 2.46 \\
& 3 & 4.26 & 1.56 & 2.17 \\
\hline \multirow{2}{*}{$\mathrm{Ca}^{2+}$} & 1 & 5.24 & 4.08 & 3.08 \\
& 3 & 3.01 & 2.12 & 2.50 \\
\hline \multirow{2}{*}{$\mathrm{Mg}^{2+}$} & 1 & 5.26 & 4.12 & 3.10 \\
\hline \multirow{2}{*}{$\mathrm{Al}^{3+}$} & 3 & 3.00 & 2.23 & 2.55 \\
\hline \multirow{2}{*}{$\mathrm{Fe}^{3+}$} & 1 & 5.27 & 4.55 & 3.28 \\
& 3 & 4.54 & 3.90 & 3.14 \\
\hline
\end{tabular}



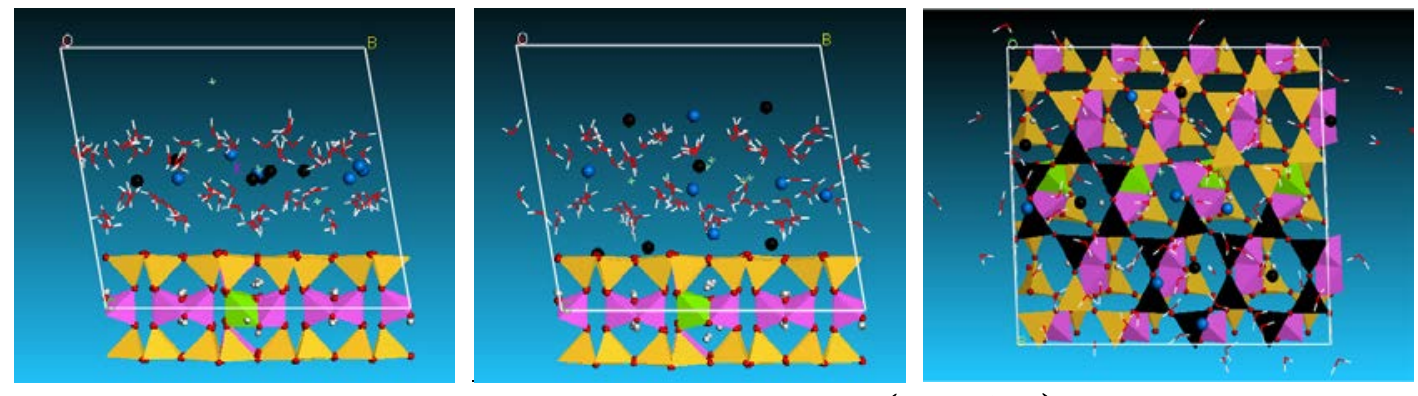

$\mathbf{T}=\mathbf{0 s}$

$\mathbf{T}=\mathbf{8 0 0 p s}$

$\mathrm{T}=800 \mathrm{ps}$ (Top view)

Fig.1 The position of $\mathrm{K}^{+}$and $\mathrm{Na}^{+}$adsorbed in the layers of Montmorillonite

$$
\text { ( “๑" is } \mathrm{K}^{+} \text {; “ } \bullet \text { " is } \mathrm{Na}^{+} \text {) }
$$

Table2 Elastic parameters of Na-montmorillonite with inorganic salts

(E for Young's modulus, K for Bulk elastic modulus, G for Shear modulus, $v$ for Poisson ratio,

C for Compressibility, $\lambda$ for Lame's constant)

\begin{tabular}{|c|c|c|c|c|c|c|c|c|}
\hline Inorganic salt & $\begin{array}{l}\text { Hydration } \\
\text { layers }\end{array}$ & $\begin{array}{c}\mathrm{K} \\
\mathrm{GPa}\end{array}$ & $\begin{array}{c}\mathrm{G} \\
\mathrm{GPa}\end{array}$ & $\begin{array}{c}\mathrm{C} \\
1 / \mathrm{TPa}\end{array}$ & $\begin{array}{c}\mathrm{E} \\
\mathrm{GPa}\end{array}$ & $\mathrm{v}$ & $\begin{array}{c}\text { Wave } \\
\text { velocity } \\
\text { km/s }\end{array}$ & $\begin{array}{c}\lambda \\
\mathrm{GPa}\end{array}$ \\
\hline \multirow{2}{*}{$\begin{array}{c}\text { Water } \\
\text { /Na-montmorillonite }\end{array}$} & 1 & 50.34 & 26.66 & 39.79 & 18.61 & \multirow{2}{*}{$\begin{array}{l}0.7 \\
0.3\end{array}$} & 2.73 & 25.68 \\
\hline & 3 & 38.75 & 17.15 & 76.62 & 11.88 & & 1.37 & 19. \\
\hline \multirow{2}{*}{$\begin{array}{c}\mathrm{NaCl} / \mathrm{Na}- \\
\text { montmorillonite }\end{array}$} & 1 & 73.28 & 37.34 & 30.21 & 21.78 & \multirow{2}{*}{$\begin{array}{l}0.5 \\
0.2\end{array}$} & 2.83 & 35.24 \\
\hline & 3 & 56.18 & 30.66 & 43.73 & 15.11 & & 1.9 & 26.30 \\
\hline \multirow{2}{*}{$\begin{array}{c}\mathrm{KCl} / \mathrm{Na}- \\
\text { montmorillonite }\end{array}$} & 1 & 72.81 & 36.79 & 34.88 & 38.38 & \multirow{2}{*}{$\begin{array}{l}\overrightarrow{0.3} \\
\overrightarrow{0.1}\end{array}$} & 2.73 & 37.73 \\
\hline & 3 & 59.93 & 32.47 & 36.19 & 24.98 & & 1.58 & 24.87 \\
\hline \multirow{2}{*}{$\begin{array}{l}\mathrm{NH}_{4} \mathrm{Cl} / \mathrm{Na}- \\
\text { montmorillonite }\end{array}$} & 1 & 63.42 & 33.40 & 29.04 & 41.19 & \multirow{2}{*}{$\begin{array}{l}\hat{0.4} \\
\hat{0.2} \\
\hat{0.2}\end{array}$} & 1.88 & 31.52 \\
\hline & 3 & 50.15 & 26.71 & 65.75 & 12.10 & & 1.58 & 22.72 \\
\hline \multirow{2}{*}{$\begin{array}{c}\mathrm{MgCl}_{2} / \mathrm{Na}- \\
\text { montmorillonite }\end{array}$} & 1 & 63.92 & 38.35 & 31.55 & 20.92 & \multirow{2}{*}{$\begin{array}{l}0.2 \\
0.4 \\
0.4\end{array}$} & 2.41 & 35.11 \\
\hline & 3 & 56.63 & 28.20 & 58.54 & 16.22 & & 2.01 & 21.6 \\
\hline \multirow{2}{*}{$\begin{array}{c}\mathrm{CaCl}_{2} / \mathrm{Na}- \\
\text { montmorillonite }\end{array}$} & 1 & 87.48 & 35.16 & 19.42 & 58.00 & \multirow{2}{*}{$\begin{array}{l}0.3 \\
0.0 \\
0.0\end{array}$} & 1.74 & 43.64 \\
\hline & 3 & 61.40 & 27.54 & 35.33 & 25.26 & & 0.80 & 19.45 \\
\hline \multirow{2}{*}{$\begin{array}{c}\mathrm{AlCl}_{3} / \mathrm{Na}- \\
\text { montmorillonite }\end{array}$} & 1 & 69.48 & 35.76 & 37.29 & 23.94 & \multirow{2}{*}{$\begin{array}{l}0.1 \\
0.3\end{array}$} & 2.50 & 29.16 \\
\hline & 3 & 56.93 & 26.19 & 44.70 & 13.04 & & 1.94 & 19.03 \\
\hline \multirow{2}{*}{$\begin{array}{c}\mathrm{FeCl}_{3} / \mathrm{Na}- \\
\text { montmorillonite }\end{array}$} & 1 & 68.83 & 38.32 & 28.66 & 28.51 & \multirow{2}{*}{$\begin{array}{l}0.2 \\
\hat{0.0}\end{array}$} & 2.83 & 36.78 \\
\hline & 3 & 45.99 & 21.58 & 69.93 & 13.47 & & 0.98 & 24.65 \\
\hline
\end{tabular}


From the simulation results of the Table 1 and Fig. 1 we can learn that both the hydration number and the hydration radius of $\mathrm{K}^{+}$and $\mathrm{NH}_{4}{ }^{+}$are smallest among all the seven inorganic cations. Since these two inorganic cations can embed into the hexatomic ring of silicon-oxygen tetrahedron, they can weaken the montmorillonite hydration and reduce the interlayer swelling tendency. However, the other cations, such as $\mathrm{Na}^{+}$, are hanging on the top of tetrahedron charges, they can only reduce the repulsion forces between the negative charges in montmorillonite interlayers, therefore their hydration number and hydration radius are relatively large.

As a whole, the elastic modulus, Lame's constant and acoustic wave velocity will reduce with the increase in water molecule number, and the compressibility will increase, which means that the crystal stability of montmorillonite become poorer. As to inorganic salt type, $\mathrm{CaCl}_{2}$ and $\mathrm{KCl}$ have the best inhibition effect, and $\mathrm{NaCl}$ is almost same as $\mathrm{NH}_{4} \mathrm{Cl}$ which are better than $\mathrm{MgCl}_{2}, \mathrm{AlCl}_{3}$ and $\mathrm{FeCl}_{3}$.

\subsection{Ion concentration}

In order to understand how the ion concentration affects on elastic mechanics parameter of montmorillonite, the different concentration of $\mathrm{NaCl}, \mathrm{KCl}$ and $\mathrm{CaCl}_{2}$ solutions were added into montmorillonite interlayers. The simulation results were listed in Table3.

Table3 The effect of cation concentration on montmorillonite elastic parameters

\begin{tabular}{|c|c|c|c|c|c|c|}
\hline $\begin{array}{c}\text { Cation } \\
\text { type }\end{array}$ & $\begin{array}{r}\text { Hydratio } \\
\text { n layers }\end{array}$ & $\begin{array}{c}\text { Concentratio } \\
\mathrm{n} \\
\mathrm{w} / \mathrm{w}\end{array}$ & $\begin{array}{c}\text { Young } \\
\text { 's } \\
\text { modulu } \\
\text { s } \\
\text { GPa } \\
\end{array}$ & $\begin{array}{c}\text { Bulk } \\
\text { elastic } \\
\text { modulu } \\
\text { s } \\
\text { GPa }\end{array}$ & $\begin{array}{c}\text { Shear } \\
\text { modulu } \\
\text { s } \\
\text { GPa }\end{array}$ & $\begin{array}{c}\text { Compressibility } \\
\text { factor } \\
1 / \mathrm{TPa}\end{array}$ \\
\hline \multirow{5}{*}{$\mathrm{NaCl}$} & \multirow{5}{*}{1} & 6.34 & 23.70 & 86.05 & 64.15 & 26.50 \\
\hline & & 11.93 & 33.89 & 77.76 & 47.03 & 36.20 \\
\hline & & 16.88 & 39.26 & 82.45 & 44.71 & 29.87 \\
\hline & & 21.31 & 40.47 & 89.58 & 95.70 & 33.60 \\
\hline & & 25.29 & 21.78 & 73.28 & 37.34 & 30.21 \\
\hline \multirow{4}{*}{$\mathrm{KCl}$} & \multirow{4}{*}{1} & 8.00 & 19.69 & 79.44 & 36.73 & 63.37 \\
\hline & & 15.00 & 27.98 & 83.11 & 52.77 & 33.93 \\
\hline & & 20.00 & 42.45 & 76.07 & 36.95 & 31.52 \\
\hline & & 25.00 & 38.38 & 72.82 & 36.79 & 34.88 \\
\hline \multirow{6}{*}{$\mathrm{CaCl}_{2}$} & \multirow{6}{*}{1} & 11.38 & 26.97 & 73.82 & 34.48 & 43.45 \\
\hline & & 20.44 & 28.26 & 75.97 & 38.52 & 27.49 \\
\hline & & 27.82 & 42.06 & 39.16 & 50.28 & 39.54 \\
\hline & & 33.94 & 52.97 & 85.14 & 45.94 & 30.34 \\
\hline & & 39.11 & 62.82 & 88.67 & 36.41 & 7.45 \\
\hline & & 43.50 & 58.00 & 87.48 & 35.16 & 19.42 \\
\hline
\end{tabular}


For $\mathrm{KCl}$, if Young's modulus, bulk elastic modulus, shear modulus and compressibility are at their ideal conditions when one layer is water saturated, $\mathrm{KCl}$ concentration is $14.7 \%-25.65 \%, 8 \%-20.55 \%, 8 \%-20.55 \%$ and $14.7 \%-25.65 \%$ respectively. Therefore, $8 \%-20.0 \%$ is selected as the best concentration range for montmorillonite crystal stability. Similarly, we can find the best concentration ranges of $\mathrm{NaCl}$ and $\mathrm{CaCl}_{2}$, which are $15.0 \%-20.0 \%$ and $37.0 \%-43.0 \%$ respectively.

\section{Experiments}

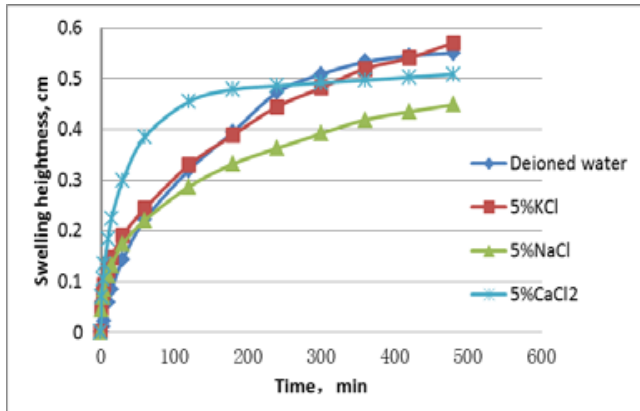

(a)

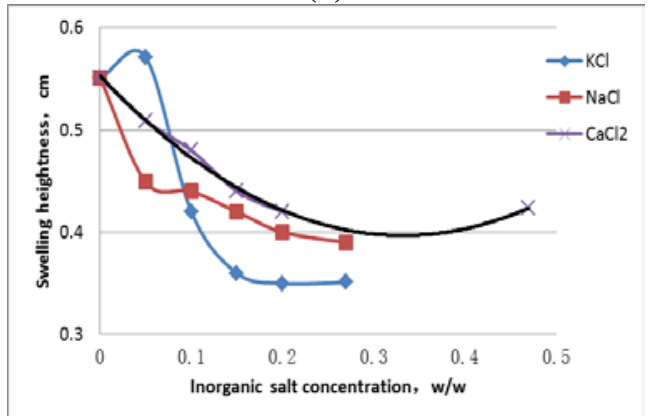

(b)

Fig.2 The swelling results of Montmorillonite in different concentration salt solutions

It can be seen from Fig.2 that the inhibition of the inorganic salts is enhanced with the concentration increase. The inhibition of $\mathrm{KCl}$ and $\mathrm{CaCl}_{2}$ are in good agreement with the simulation results. The inhibition of $\mathrm{NaCl}$ is weakened after its concentration is over $20 \% \mathrm{w} / \mathrm{w}$, which conforms to simulation conclusion. The experiment results showed that the inorganic ions can exchange intensely when the concentration of inorganic salt solutions is high. Such exchange changed the interior structure and ion composition of montmorillonite, which is harmful to the borehole stability.

The acoustic velocity experiments results were listed in Table 4. And the comparison between simulated results and experiment result of the Young's modulus were shown in Fig.3.

Table4 Change of montmorillonite mechanical parameters with inorganic salt concentration 


\begin{tabular}{|c|c|c|c|c|c|c|c|c|c|c|c|c|c|c|c|}
\hline & \multicolumn{5}{|c|}{$\mathrm{NaCl}$ w/w,$\%$} & \multicolumn{5}{|c|}{$\mathrm{KCl} \mathrm{w/w}, \%$} & \multicolumn{5}{|c|}{$\mathrm{CaCl}_{2} \mathrm{w} / \mathrm{w}, \%$} \\
\hline & 5 & 10 & 15 & 20 & 25 & 5 & 10 & 15 & 20 & 25 & 10 & 20 & 30 & 40 & 45 \\
\hline $\begin{array}{c}\rho \\
\times 10^{3} \mathrm{~kg} / \\
\mathrm{m}^{3}\end{array}$ & $\begin{array}{c}2.5 \\
5\end{array}$ & $\begin{array}{c}2.5 \\
4\end{array}$ & $\begin{array}{c}2.5 \\
5\end{array}$ & $\begin{array}{c}2.5 \\
6\end{array}$ & $\begin{array}{c}2.5 \\
6\end{array}$ & $\begin{array}{c}2.5 \\
4\end{array}$ & $\begin{array}{c}2.5 \\
5\end{array}$ & $\begin{array}{c}2.5 \\
6\end{array}$ & $\begin{array}{c}2.5 \\
5\end{array}$ & $\begin{array}{c}2.5 \\
6\end{array}$ & $\begin{array}{c}2.5 \\
5\end{array}$ & $\begin{array}{c}2.5 \\
6\end{array}$ & $\begin{array}{c}2.5 \\
6\end{array}$ & $\begin{array}{c}2.5 \\
7\end{array}$ & $\begin{array}{c}2.5 \\
7\end{array}$ \\
\hline $\begin{array}{l}C_{P} \\
\mathrm{~km} / \mathrm{s}\end{array}$ & $\begin{array}{c}1.7 \\
0\end{array}$ & $\begin{array}{c}1.7 \\
3\end{array}$ & $\begin{array}{c}1.7 \\
5\end{array}$ & $\begin{array}{c}1.7 \\
6\end{array}$ & $\begin{array}{c}1.7 \\
4\end{array}$ & $\begin{array}{c}1.7 \\
2\end{array}$ & $\begin{array}{c}1.7 \\
3\end{array}$ & $\begin{array}{c}1.7 \\
4\end{array}$ & $\begin{array}{c}1.7 \\
5\end{array}$ & $\begin{array}{c}1.7 \\
2\end{array}$ & $\begin{array}{c}1.7 \\
1\end{array}$ & $\begin{array}{c}1.7 \\
3\end{array}$ & $\begin{array}{c}1.7 \\
5\end{array}$ & $\begin{array}{c}1.7 \\
6\end{array}$ & $\begin{array}{c}1.7 \\
3\end{array}$ \\
\hline $\begin{array}{l}C_{T}, \\
\mathrm{~km} / \mathrm{s}\end{array}$ & $\begin{array}{c}0.8 \\
6\end{array}$ & $\begin{array}{c}0.8 \\
7\end{array}$ & $\begin{array}{c}0.8 \\
8\end{array}$ & $\begin{array}{c}0.9 \\
5\end{array}$ & $\begin{array}{c}0.9 \\
2\end{array}$ & $\begin{array}{c}0.8 \\
4\end{array}$ & $\begin{array}{c}0.8 \\
6\end{array}$ & 0.9 & $\begin{array}{c}0.9 \\
3\end{array}$ & $\begin{array}{c}0.8 \\
8\end{array}$ & $\begin{array}{c}0.8 \\
5\end{array}$ & $\begin{array}{c}0.8 \\
7\end{array}$ & $\begin{array}{c}0.9 \\
1\end{array}$ & $\begin{array}{c}0.9 \\
2\end{array}$ & $\begin{array}{c}0.8 \\
7\end{array}$ \\
\hline$E$, МРа & $\begin{array}{c}49.1 \\
4\end{array}$ & $\begin{array}{c}50.2 \\
0\end{array}$ & $\begin{array}{c}51.6 \\
0\end{array}$ & $\begin{array}{c}58.6 \\
8\end{array}$ & $\begin{array}{c}55.5 \\
2\end{array}$ & $\begin{array}{c}47.2 \\
4\end{array}$ & $\begin{array}{c}49.4 \\
3\end{array}$ & $\begin{array}{c}53.6 \\
0\end{array}$ & $\begin{array}{c}56.4 \\
0\end{array}$ & $\begin{array}{c}51.4 \\
5\end{array}$ & $\begin{array}{c}48.2 \\
9\end{array}$ & $\begin{array}{c}50.5 \\
9\end{array}$ & $\begin{array}{c}54.6 \\
8\end{array}$ & $\begin{array}{c}55.9 \\
9\end{array}$ & $\begin{array}{c}50.7 \\
9\end{array}$ \\
\hline$\sigma$ & $\begin{array}{c}0.3 \\
3\end{array}$ & $\begin{array}{c}0.3 \\
3\end{array}$ & $\begin{array}{c}0.3 \\
3\end{array}$ & $\begin{array}{c}0.2 \\
9\end{array}$ & $\begin{array}{c}0.3 \\
1\end{array}$ & $\begin{array}{c}0.3 \\
4\end{array}$ & $\begin{array}{c}0.3 \\
4\end{array}$ & $\begin{array}{c}0.3 \\
2\end{array}$ & $\begin{array}{c}0.3 \\
0\end{array}$ & $\begin{array}{c}0.3 \\
2\end{array}$ & $\begin{array}{c}0.3 \\
4\end{array}$ & $\begin{array}{c}0.3 \\
3\end{array}$ & $\begin{array}{c}0.3 \\
1\end{array}$ & $\begin{array}{c}0.3 \\
1\end{array}$ & $\begin{array}{c}0.3 \\
3\end{array}$ \\
\hline$R$, МРа & $\begin{array}{c}5.7 \\
6\end{array}$ & $\begin{array}{c}5.8 \\
8\end{array}$ & $\begin{array}{c}6.0 \\
3\end{array}$ & $\begin{array}{c}6.1 \\
5\end{array}$ & $\begin{array}{c}6.1 \\
0\end{array}$ & $\begin{array}{c}5.6 \\
8\end{array}$ & $\begin{array}{c}5.6 \\
6\end{array}$ & $\begin{array}{c}5.9 \\
0\end{array}$ & $\begin{array}{c}6.1 \\
6\end{array}$ & $\begin{array}{c}6.0 \\
2\end{array}$ & $\begin{array}{c}5.9 \\
0\end{array}$ & $\begin{array}{c}5.9 \\
2\end{array}$ & $\begin{array}{c}6.0 \\
4\end{array}$ & $\begin{array}{c}6.0 \\
3\end{array}$ & $\begin{array}{c}6.0 \\
2\end{array}$ \\
\hline
\end{tabular}
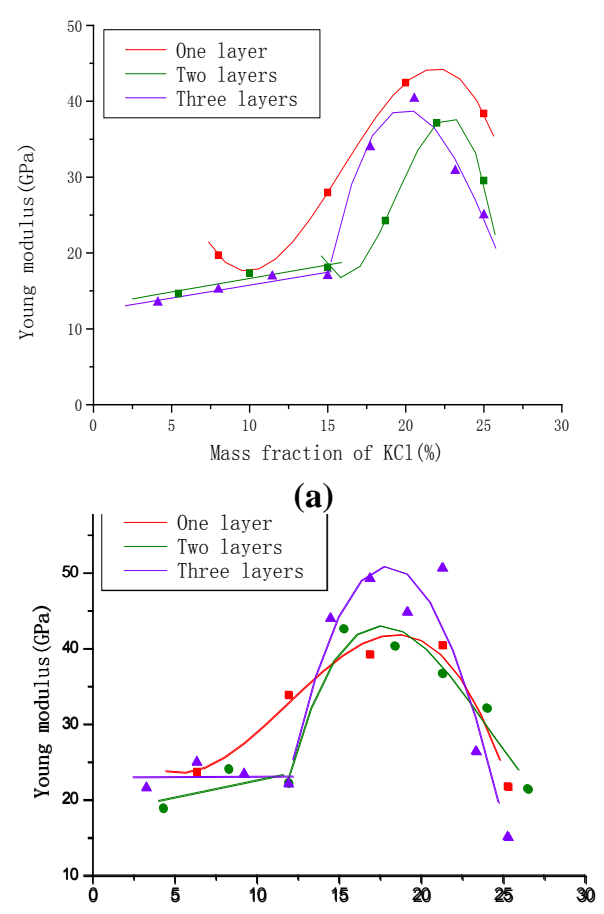

(b) 


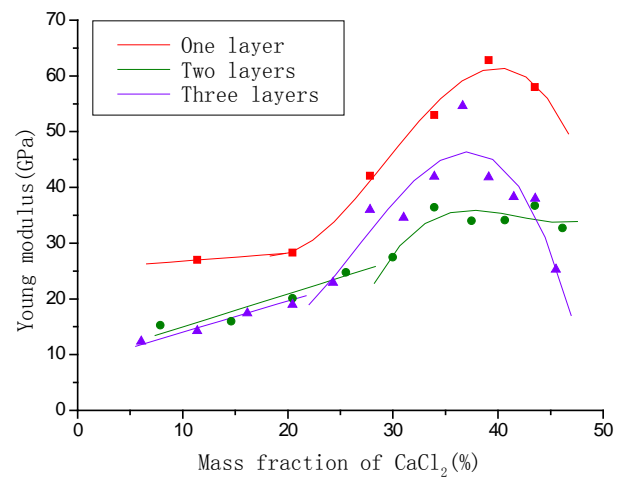

(c)

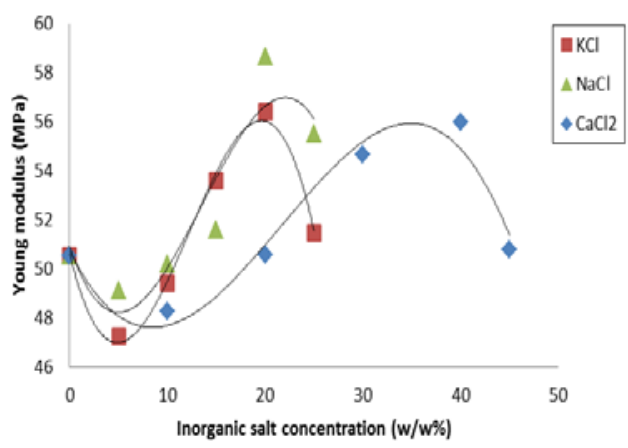

(d)

Fig.3 The fitting curves of Montmorillonite Young modulus with the amount of inorganic salts

The results shown in Table 4 and Fig.3 demonstrated that the strength parameters of montmorillonite depend on not only water content but also the different inorganic salt type and concentration. The appropriate salt concentration is favorable to improve the rock strength, rather than the greater the concentration, the better. The experiment results with various water content and inorganic salt concentrations verified the validity of the simulation results.

\section{Conclusions}

1. The simulation results showed that the first, second and third saturation hydrate layers were formed when the absorbing water molecules amount to 48, 72 and 96 irrespectively. From the radial distribution functions we can conclude that the ion coordinate, ion hydration number and ion hydration radius of interlayer balance cation $\mathrm{Na}^{+}$in montmorillonite all reduced with the increase in interlayer absorbed water, which indicated that montmorillonite hydration was weakened. 
2.The simulation results showed that $\mathrm{CaCl}_{2}$ and $\mathrm{KCl}$ have the best borehole stability effect among seven simulated chloride salts. Montmorillonite is salt sensitive. The best concentration range of $\mathrm{CaCl}_{2}, \mathrm{NaCl}$ and $\mathrm{KCl}$ which can keep montmorillonite stable are given.

3. The swelling and acoustic velocity experiments are in good agreement with the simulation conclusions. The results provide a good means for further studying borehole stability with coupling chemistry with mechanics.

\section{Acknowledgements}

This work was financially supported by the Nature Science Foundation of China (41072094); Nature Science Foundation of Shandong Provence, China (ZR2012EEM020), Innovation Research Team of Educational Ministry of PRC

(IRT1086), the Fundamental Research Funds for the Central Universities(24720136030).

\section{References}

[1] Chenevert ME. Adsorptive Pore Pressure of Argillaceous Rocks[R]. The llth Symposium on Rock Mechanics. June16-19, 1969.

[2] Jiafang $\mathrm{Xu}$, Zhengsong Qiu. Journal of China University of Petroleum(Edition of Natural Science), 2006, 30(3): 63 66.

[3] Jingyin Wang. Chemical-Mechanical Modeling of Borehole Stability in Shale [D]. Qingdao of Shandong Province: China University of Petroleum, 2007.

[4] Skipper NT, Chang FR, Sposito G.. Clays Clay Miner, 1995, 43: 285 293.

[5] Jin Wang, Fangui Zeng. Journal of Chinese Ceramic Society, 2005, 33(8), 995 1001 .

[6] Ping Na, Fan Zhang, Yanni Li. Acta Physico-Chimica Sinica, 2006, 22(9), $1137 \sim 1142$. 